[Agr. Biol. Chem., Vol. 27, No. 3, p. 199 204, 1963]

\title{
Degradation of Nucleic Acids and their Related Compounds by Microbial Enzymes
}

\author{
Part III. On the Distribution of Extracellular Enzymes Capable of \\ Degrading Deoxyribonucleic Acid into 5'-Deoxymononucleotides \\ in Microorganisms.*
}

By Yoshio Nakao and Koichi Ogata**

Research Laboratories, Takeda Chemical Industries, Ltd., Osaka

Received October 22, 1962

\begin{abstract}
The distribution in microorganisms of extracellular enzymes which degrade DNA into deoxymononucleotides was studied. The degradation products of DNA were determined by using $5^{\prime}$-nucleotidase and prostatic nonspecific phosphomonoesterase. It was found that except Bacillus subtilis IFO 3302, the microorganisms which produced the enzymes that catalyze the degradation of RNA into 5'-mononucleotides, produced the enzymes capable of hydrolyzing DNA into 5'-deoxymononucieotides, whereas the microorganisms which produced such enzymes that degrade RNA into 3 '-mononucleotides did not generally produce the enzymes which hydrolyze DNA.
\end{abstract}

\section{INTRODUCTION}

It was previously reported that the phosphodiesterases capable of hydrolyzing RNA into 5'-mononucleotides were produced by various microorganisms ${ }^{1)}$, and other microorganisms produced the phosphodiesterases capable of degrading RNA into 3'-mononucleotides $^{2)}$. From these findings, it has become possible to produce economically $5^{\prime}$ mononucleotides and $3^{\prime}$-mononucleotides, the former is regarded as a new chemical seasoning agent. Deoxymononucleotides and their derivatives are important not only as biochemical reagents but also as medicines. However, it is difficult to produce deoxymononucleotides on a large scale. In order to

* The report was presented at the Meeting of the Kanto Division of the Agricultural Chemical Society of Japan, Tokyo, November 12, 1960. ** Present address: Department of Agricultural Chemistry, Kyoto University Kyoto.

The abbreviations used are: RNA, Ribonucleic acid; INA, Deoxyribonucleic acid; DNase, Deoxyribonuclease; TCA, Trichloroacetic acid; Tris buffer, Tris (hydroxymethyl) aminomethane buffer.

1) K. Ogata, et al., This journal, 27, 110 (1963).

2) Y. Nakao and K. Ogata, ibid., 27, 116 (1963). produce them economically, we searched for species and strains which produce extracellular enzymes capable of degrading DNA into deoxymononucleotides. The present communication is concerned with the distribution of the enzymes in microorganisms.

\section{EXPERIMENTAL}

\section{Materials.}

Organisms. All the strains were supplied by the Institute for Fermentation, Osaka.

Enzyme solutions were prepared by the same method as that described in the previous paper $^{2}$.

Enzymes for Assay. 5'-Nucleotidase and non-specific phosphomonoesterase were prepared by the methods previously described ${ }^{2)}$. Sperm DNA and calf thymus DNA were purchased from Nutritional Biochemicals Corporation and Worthington Biochemical Corporation, respectively.

Methods. In order to search for the strains, which produce enzymes capable of degrading DNA into deoxymononucleotides, a large number of microorganisms were subjected to screening tests consisting of two steps. 
In the first screening test, the activities of DNase and phosphomonoesterase in the enzyme preparations were examined. In the second screening test, it was tested whether the enzyme preparations could degrade DNA into 5'-deoxymononucleotides or 3'-deoxymononucleotides.

The First Screening Test. Although many methods ${ }^{3)}$ of assaying DNase have been reported, McDonald colorimetric procedure ${ }^{4}$ is probably the most convenient for routine measurements of DNase in many enzyme preparations. DNase activity was measured, therefore, by the method of McDonald with some modification.

One-half $\mathrm{ml}$ of $1.0 \%$ sperm DNA solution, $1.0 \mathrm{ml}$ of $0.5 \mathrm{M}$ acetate buffer ( $\mathrm{pH} 5.0$ ) or $0.5 \mathrm{M}$ Tris buffer (pH 7.5) and $0.5 \mathrm{ml}$ of an enzyme solution were mixed. After incubation at $37^{\circ} \mathrm{C}$ for 120 minutes, the reaction was stopped by addition of $2.0 \mathrm{ml}$ of a modified McFadyen's reagent ${ }^{5}$ ) (UPCA solution, $0.25 \%$ uranyl acetate in $2.5 \%$ perchloric acid). The mixture was left in an ice-water bath for 15 minutes, then the precipitate was removed by centrifugation. One-half $\mathrm{ml}$ of the supernatant was diluted to $2.0 \mathrm{ml}$ with distilled water and then mixed with $4.0 \mathrm{ml}$ of the diphenylamine reagen $t^{\beta}$. The mixture was heated for 10 minutes in a boiling water bath, and after cooling, the optical density (D) at $595 \mathrm{~m}_{\mu}$ was read in a Hitachi EPU-2A spectrophotometer with a $1 \mathrm{~cm}$ light path against the control. Controls were run in each experiment by addition of the substrate after the addition of UPCA solution. The rate of DNA-degradation was calculated from the following equation;

$$
\mathrm{D} / \mathrm{T} \times 100
$$

D: the optical density at $595 \mathrm{~m}_{\mu}$ measured as above. T: the optical density at $595 \mathrm{~m}_{\mu}$ measured by the following method. One-half $\mathrm{ml}$ of $1.0 \%$ sperm DNA solution was diluted to $4.0 \mathrm{ml}$ with distilled water and $0.5 \mathrm{ml}$ aliquot was treated by the same method as described above and then the optical density (T) at $595 \mathrm{~m}_{\mu}$ was measured.

The orthophosphate liberated during the degradation of DNA was determined by the method of

\footnotetext{
3) N.B. Kurnick, "Methods of Biochemical Analysis", Vol. 9, Interscience Publishers, 1962, p. 1.

4) S.P. Colowick and N.O. Kaplan, "Methods in Enzymology", Vol. II, Academic Press, 1955, p. 437.

5) S.P. Colowick and N.O. Kaplan, ibid., Vol. III, Academic Press, 1955 , p. 771 .

6) E. Chargaff and J.N. Davidson, "The Nucleic Acids", Vol. I, Academic Press, 1955, p. 287.

7) C.H. Fiske and Y. Subbarow, J. Biol. Chem., 66, 375 (1925).
}

Fiske-Subbarow ${ }^{7}$ as follows: four tenths $\mathrm{ml}$ of the supernatant fluid, $0.2 \mathrm{ml}$ of $10 \mathrm{~N} \mathrm{H}_{2} \mathrm{SO}_{4}, 0.4 \mathrm{ml}$ of $2.5 \%$ ammonium molybdate and $0.2 \mathrm{ml}$ of reducing reagent were mixed and diluted to $5.0 \mathrm{ml}$ with distilled water, and was left to stand for 20 minutes at $37^{\circ} \mathrm{C}$; the optical density $(\mathrm{Pi})$ of the mixture at $660 \mathrm{~m} \mu$ was read in a Coleman Junior spectrophotometer against the control. The rate of orthophosphate liberation was calculated from the following equation:

$$
\mathrm{Pi} / \mathrm{T} \times 100 \text {. }
$$

Pi: the optical density at $660 \mathrm{~m} \mu$ measured as above.

$\mathrm{T}$ : the optical density at $660 \mathrm{~m} \mu$ measured by the following method. One-half $\mathrm{ml}$ of $1.0 \%$ sperm DNA solution was mixed with $1.6 \mathrm{ml}$ of $10 \mathrm{~N} \quad \mathrm{H}_{2} \mathrm{SO}_{4}$ and DNA-P was converted to orthophosphate by heating the mixture. The mixture was cooled, and adjusted to $10 \mathrm{ml}$ with distilled water, and the orthophosphate in $1.0 \mathrm{ml}$ aliquot of the solution was determined as described above without further addition of sulfuric acid.

The Second Screening Test. This test was carried out to estimate the degradation products of DNA. In this case, sodium arsenate was added to the reaction mixture to inhibit phosphomonoesterase activity, and the rates of DNA degradation and of formation of 5'- and 3'-deoxymononucleotides were estimated. The procedure is described below.

The total volume of an incubation mixture of $2.0 \mathrm{ml}$ was made to contain $0.5 \mathrm{ml}$ of $1.0 \%$ sperm DNA solution, $0.2 \mathrm{ml}$ of $0.25 \mathrm{M}$ sodium arsenate, $0.3 \mathrm{ml}$ of $1 \mathrm{M}$ acetate buffer $(\mathrm{pH} 5.0)$ or $1 \mathrm{M}$ Tris buffer (pH 7.5) and an enzyme solution. The amount of the enzyme solution necessary for complete hydrolysis of DNA was determined from the results of the first screening test. After the mixture was incubated for 8 hours at $37^{\circ} \mathrm{C}$, a $1.0 \mathrm{ml}$ aliquot mixed with $1.0 \mathrm{ml}$ of UPCA solution, and the rates of DNA degradation and of orthophosphate liberation were determined by the method described in the first screening test.

Another $1.0 \mathrm{ml}$ aliquot was diluted to $5.0 \mathrm{ml}$ with distilled water and heated in a boiling water bath for 5 minutes to stop the reaction. This solution was used as a sample for the determination of $5^{\prime}$ - and 3'-deoxymononucleotides. The 5'- and $3^{\prime}$-deoxymononucleotides in $0.4 \mathrm{ml}$ portions of the sample were respectively determined by the method described in the previous paper"). Rate of the formation of $5^{\prime}$ - or 3 -deoxymononucleotides was represented respectively in perrentage of $5^{\prime}$-deoxymononucleotidle phosphate or 
3'-deoxymononucleotide phosphate in the enzymatic hydrolyzate to total phosphates in the DNA used as substrate.

\section{RESULTS}

I. Distribution of Enzymes Capable of Hydrolyzing DNA into Deoxymononucleotides in Streptomyces and Bacteria.

Table I illustrates the result obtained. DNA-depolymerases in the culture media of Streptomyces and bacteria were active at the alkaline $\mathrm{pH}$ and hydrolyzed DNA into 5'deoxymononucleotides.

II. Distribution of Enzymes Capable of Degrading DNA into Deoxymononucleotides in Molds.

The results are shown in Table II. About 90 strains were tested and DNA-depolymerases in the culture media of molds were generally active at the alkaline $\mathrm{pH}$, while the strains belonging to Monascus and Phytophthora infestans produced enzymes which were active at the acid pH. However, all the enzymes degraded DNA into 5'-deoxymononucleotides.

Furthermore we tested about 50 strains of yeasts for their ability to produce DNA-depolymerase but no strain capable of hydrolyzing DNA was found.

In the preliminary experiments, we found that sperm DNA employed as substrate in these studies was partially degraded during the extraction procedures because it was in part soluble in $3 \mathrm{M}$ TCA solution. So we tested DNA-depolymerase activity of the enzyme preparations using thymus highly polymerized DNA as substrate. As a result, it was found that the enzymes which was produced by the strains described in Tables I and II

TABle I. Distribution of ENZymes CAPABle of Hydrolyzing DNA into DeoxymononucLEOTIDES IN BACTERIA AND Streptomyces

\begin{tabular}{|c|c|c|c|c|c|c|c|c|c|c|}
\hline \multirow{3}{*}{$\begin{array}{l}\text { IFO } \\
\text { No. }\end{array}$} & & \multicolumn{4}{|c|}{ First scrcening } & \multicolumn{5}{|c|}{ Second screening } \\
\hline & \multirow{2}{*}{ Microorganism } & \multicolumn{2}{|c|}{$\begin{array}{l}\text { Degradation } \\
\text { of DNA }(\%)\end{array}$} & \multicolumn{2}{|c|}{$\begin{array}{c}\text { Liberation } \\
\text { of } \mathrm{Pi}^{*}(\%)\end{array}$} & \multirow{2}{*}{$\begin{array}{l}\text { pH of } \\
\text { Degra- } \\
\text { dation }\end{array}$} & \multirow{2}{*}{$\begin{array}{c}\text { Degra- } \\
\text { dation } \\
\text { of DNA } \\
(\%)\end{array}$} & \multirow{2}{*}{$\begin{array}{l}\text { Forma- } \\
\text { tion of } \\
5^{\prime} \text {-nucle- } \\
\text { otide }(\%)\end{array}$} & \multirow{2}{*}{$\begin{array}{c}\text { Forma- } \\
\text { tion of } \\
3^{\prime} \text {-nucle- } \\
\text { otide }(\%)\end{array}$} & \multirow{2}{*}{$\begin{array}{c}\text { Libera- } \\
\text { tinn of } \\
\mathrm{Pi}^{*} \\
(\%)\end{array}$} \\
\hline & & pH 5.0 & $\mathrm{pH} 7.5$ & pH 5.0 & $\mathrm{pH} 5.0$ & & & & & \\
\hline 3022 & Bacillus subtilis & 0 & 0 & 0 & 0 & & & & & \\
\hline 3032 & $\prime \prime \quad 11$ & 0 & 0 & 0 & 0 & & & & & \\
\hline 3010 & $\prime \prime$ & 0 & 21.5 & 0 & 7.6 & 7.5 & 56.0 & 24.5 & 0 & 28.5 \\
\hline 3331 & brevis & 0 & 40.0 & 0 & 23.5 & $\prime \prime$ & 74.3 & 42.0 & 0 & 21.5 \\
\hline 3028 & pumilus & 0 & 0 & 0 & 0 & & & & & \\
\hline 3132 & $\prime \prime \quad$ cereus & 0 & 0 & 0 & 0 & & & & & \\
\hline 3366 & Escherichia coli & 0 & 0 & 0 & 0 & & & & & \\
\hline 3140 & Pseudomonas riboflavina & 0 & 0 & 0 & 0 & & & & & \\
\hline 3080 & " aeruginosa & 0 & 0 & 0 & 0 & & & & & \\
\hline 3062 & Micrococcus subflavus & 0 & 0 & 0 & 0 & & & & & \\
\hline 3242 & " $\quad$ flavus & 0 & 0 & 0 & 0 & & & & & \\
\hline 3333 & lys.odeikticus & 0 & 0 & 0 & 0 & & & & & \\
\hline 3060 & pyogenes var. aureus & 0 & 0 & 0 & 0 & & & & & \\
\hline 3183 & "1 & 0 & 0 & 0 & 0 & & & & & \\
\hline 3332 & $\prime \prime \quad$ citreus & 0 & 0 & 0 & 0 & & & & & \\
\hline 3380 & Erwinia carotovora & 0 & 15.4 & 0 & 5.9 & 7.5 & 52.0 & 20.1 & 0 & 23.1 \\
\hline 3303 & Streptomyces aureus & 8.0 & 73.0 & 3.0 & 50.0 & $\prime \prime$ & 100.0 & 52.0 & 0 & 31.5 \\
\hline 3113 & "l viridochromogenus & $s 0$ & 13.8 & 0 & 0 & $\prime \prime$ & 71.0 & 26.0 & 0 & 0 \\
\hline \multirow[t]{2}{*}{3389} & purpurascens & 0 & 20.0 & 0 & 5.4 & $\prime \prime$ & 55.0 & 21.5 & 0 & 7.5 \\
\hline & spec. & 0 & 36.5 & 0 & 27.0 & $\prime \prime$ & 100.0 & 26.0 & 0 & 10.5 \\
\hline
\end{tabular}

*Pi : orthophosphate. 
TABle II. Distribution of Enzymes Gapable of Hydrolyzing DNA into DeoxymonoNUCLEOTIDES IN MOLDS

\begin{tabular}{|c|c|c|c|c|c|c|c|c|c|c|}
\hline \multirow{3}{*}{$\begin{array}{l}\text { IFO } \\
\text { No. }\end{array}$} & \multirow{3}{*}{ Microorganism } & \multicolumn{4}{|c|}{ First screening } & \multicolumn{5}{|c|}{ Second screening } \\
\hline & & \multicolumn{2}{|c|}{$\begin{array}{l}\text { Degradation } \\
\text { of DNA }(\%)\end{array}$} & \multicolumn{2}{|c|}{$\begin{array}{l}\text { Liberation } \\
\text { of Pi* }(\%)\end{array}$} & \multirow{2}{*}{$\begin{array}{c}\text { pH of } \\
\text { Degra- } \\
\text { dation }\end{array}$} & \multirow{2}{*}{$\begin{array}{c}\text { Degra- } \\
\text { dation } \\
\text { of DNA } \\
(\%)\end{array}$} & \multirow{2}{*}{$\begin{array}{l}\text { Forma- } \\
\text { tion of } \\
5^{\prime} \text {-nucle- } \\
\text { otide }(\%)\end{array}$} & \multirow{2}{*}{$\begin{array}{l}\text { Forma- } \\
\text { tion of } \\
3^{\prime} \text {-nucle- } \\
\text { otide }(\%)\end{array}$} & \multirow{2}{*}{$\begin{array}{l}\text { Libera- } \\
\text { tion of } \\
\mathrm{Pi}^{*} \\
(\%)\end{array}$} \\
\hline & & $\mathrm{pH} 5.0$ & $\mathrm{pH} 7.5$ & $\mathrm{pH} 5.0$ & $\mathrm{pH} 7.5$ & & & & & \\
\hline 4434 & Absidia butleri & 0 & 0 & 0 & 0 & & & & & \\
\hline 4435 & "I coerulea & 0 & 0 & 0 & 0 & & & & & \\
\hline 5873 & "I spinosa & 0 & 6.0 & 0 & 0 & & & & & \\
\hline 5242 & Acrocylindrium spec. & 20.0 & 90.8 & 14.0 & 49.5 & 7.5 & 96.0 & 43.0 & 0 & 21.5 \\
\hline 5864 & Aspergillus. fonsecaeus & 0 & 15.4 & 0 & 0 & $\prime \prime$ & 40.1 & 40.0 & 0 & 0 \\
\hline 4031 & "I foetidus & 0 & 12.0 & 0 & 0 & $\prime \prime$ & 51.5 & 34.0 & 0 & 0 \\
\hline 4053 & flavus & 0 & 15.4 & 0 & 0 & $\prime \prime$ & 56.5 & 36.5 & 0 & 0 \\
\hline 4066 & niger & 0 & 0 & 0 & 0 & & & & & \\
\hline 5374 & "l & 0 & 0 & 0 & 0 & & & & & \\
\hline 5376 & $\prime \prime$ & 0 & 0 & 0 & 0 & & & & & \\
\hline 5866 & fischeri & 0 & 34.0 & 0 & 5.4 & 7.5 & 90.0 & 68.0 & 0 & 2.7 \\
\hline 4052 & flavipes & 0 & 18.4 & 0 & 0 & $\prime \prime$ & 100.0 & 74.0 & 0 & 2.7 \\
\hline 4339 & melleus & 0 & 17.0 & 0 & 3.8 & $\prime \prime$ & 95.0 & 71.0 & 0 & 0 \\
\hline 4363 & quercinus & 0 & 38.5 & 0 & 2.0 & $\prime \prime$ & 82.0 & 67.0 & 0 & 0 \\
\hline 4094 & "I sulphureus & 0 & 51.0 & 0 & 3.8 & $\prime \prime$ & 70.7 & 63.0 & 0 & 0 \\
\hline 5483 & Anixiella reticulispora & 0 & 15.2 & 0 & 2.1 & $\prime \prime$ & 86.0 & 58.0 & 0 & 14.0 \\
\hline 5991 & Blackeslea circinans & 0 & 0 & 0 & 0 & & & & & \\
\hline 4837 & Botryoshaeria ribis chromogena & 0 & 40.0 & 0 & 5.3 & 7.5 & 95.0 & 66.0 & 3.0 & 8.0 \\
\hline 6142 & Corticium centrifugum & 6.2 & 10.7 & 5.9 & 0.5 & & & & & \\
\hline 4442 & Cunninghamella echinulata & 6.2 & 10.7 & 3.5 & 2.7 & 7.5 & 27.5 & 10.5 & 0 & 0 \\
\hline 4441 & "I elegans & 0 & 7.7 & 0 & 1.0 & $\prime \prime$ & 25.5 & 10.0 & 0 & 0 \\
\hline 4451 & Chaetomidium japonicum & 0 & 16.0 & 0 & 8.0 & $\prime \prime$ & 67.6 & 37.0 & 0 & 31.0 \\
\hline 5421 & Fusarium roseum & 4.0 & 10.6 & 0 & 0 & $\prime \prime$ & 71.4 & 59.5 & 0 & 8.6 \\
\hline 5893 & "I solani & 0 & 15.4 & 0 & 5.4 & 11 & 74.3 & 47.5 & 0 & 21.5 \\
\hline 5952 & Gloeosporium laeticolor & 0 & 10.8 & 0 & 0 & $\prime \prime$ & 80.0 & 76.0 & 0 & 0 \\
\hline 5907 & Glomerella cingulata & 6.0 & 37.0 & 0 & 4.3 & 7.5 & 91.0 & 72.0 & 0 & 5.4 \\
\hline 4871 & Gliomastix convoluta & 0 & 37.0 & 0 & 14.2 & $\prime \prime$ & 80.0 & 44.5 & 0 & 28.5 \\
\hline 4475 & Helicostylum piriforme & 0 & 0 & 0 & 0 & & & & & \\
\hline 5273 & $\begin{array}{l}\text { Helminthosporium sigmoideum } \\
\text { var. irregulare }\end{array}$ & 5.0 & 63.0 & 2.0 & 20.0 & 7.5 & 92.4 & 60.0 & 0 & 11.8 \\
\hline 5367 & Irpex lacteus & 0 & 0 & 0 & 0 & & & & & \\
\hline 4946 & Lenzites tenuis. & 0 & 0 & 0 & 0 & & & & & \\
\hline 4480 & Monascus pilosus & 50.8 & 29.2 & 31.2 & 10.2 & 5.0 & 35.5 & 20.0 & 0 & 2.0 \\
\hline 4485 & "I major & 94.0 & 64.7 & 76.3 & 25.8 & 5.0 & 24.5 & 18.5 & 0 & 2.0 \\
\hline 4487 & serorubescens & 58.5 & 30.8 & 35.5 & 3.8 & 5.0 & 44.6 & 38.0 & 0 & 3.0 \\
\hline 4489 & albidus & 61.5 & 47.7 & 32.5 & 5.4 & 5.0 & 55.5 & 33.5 & 0 & 4.8 \\
\hline 4498 & spec. & 33.3 & 50.8 & 11.8 & 5.4 & 7.5 & 54.0 & 39.0 & 0 & 2.0 \\
\hline 4478 & "I anka & 10.0 & 24.5 & 5.4 & 2.7 & 7.5 & 38.5 & 28.0 & 0 & 0 \\
\hline 4578 & Mucor pusillus & 6.2 & 4.6 & 4.3 & 1.6 & & & & & \\
\hline 4585 & "I genevensis & 0 & 5.0 & 0 & 0 & & & & & \\
\hline 6067 & Neurospora crassa & 3.0 & 21.5 & 2.0 & 7.8 & 7.5 & 87.7 & 58.0 & 0 & 22.0 \\
\hline 6069 & " sitophila & 14.0 & 37.0 & 8.5 & 9.2 & $\prime \prime$ & 96.0 & 50.0 & 0 & 28.5 \\
\hline 6026 & Penicillium citrinum & 4.6 & 0 & 2.1 & 0 & & & & & \\
\hline 6092 & " corymbiferum & 3.1 & 1.5 & 2.7 & 0 & & & & & \\
\hline
\end{tabular}


Degradation of Nuclcic Acids and their Related Compounds by Microbial Enzymes Part III

(Continued)

\begin{tabular}{|c|c|}
\hline $\begin{array}{l}\text { IFO } \\
\text { No. }\end{array}$ & Microorganism \\
\hline 6090 & Penicillium baarnense var. \\
\hline 6088 & " asperum \\
\hline 6014 & "I crustosum \\
\hline 5282 & Pestalotia diospyri \\
\hline 5427 & Pestalotiopsis funerea \\
\hline 5822 & Phycomyces blakesleeanus \\
\hline 4872 & Phytophthora infestans \\
\hline 4935 & Polyporus orientalis \\
\hline 4917 & Polystictus hirsutus \\
\hline 4937 & "I versicolor \\
\hline 4927 & Poria vaporaria \\
\hline 5911 & Sclerotinia fuckeliana \\
\hline 4745 & Rhizopus chinensis \\
\hline 4759 & $\prime \prime \quad$ niveus \\
\hline 5696 & $\begin{array}{l}\text { Tilachlidium humicola } \\
\qquad * \mathrm{Pi} \text { : orthophosphate. }\end{array}$ \\
\hline
\end{tabular}

hydrolyzed the thymus highly polymerized DNA also.

\section{DISCUSSION}

It is apparent from the data presented here that large number of microorganisms such as Streptomyces, bacteria, and molds produce extracellular enzymes which degrade DNA into $5^{\prime}$-deoxymononucleotides.

$5^{\prime}$-Deoxymononucleotides have been hitherto produced from DNA by using DNase I and phosphodiesterase from snake venom ${ }^{8)}$ or intestinal mucosa ${ }^{9}$. However, these methods possess the defect that the enzymes are not obtained in a large quantity. On the basis of the results obtained here, 5'-deoxymononucleotides may be produced easily from DNA by means of microbial enzymes. This method is very favorable for the production of $5^{\prime}$ deoxymononucleotides, because it is extremely easy to obtain enzyme solution on a large scale.

\footnotetext{
8) R.O. Hurst, J.A. Little and G.C. Butler, J. Biol. Chem., 188, 705 (1951).

9) E. Volkin, J.X. Khym and W.F. Cohn, J. Am. Chem. Soc., 73, 1533 (1951).
}

Previously, we investigated the distribution of RNA-hydrolyzing enzymes in various mic-roorganisms. Comparing the present results with those in the previous reports ${ }^{1,2)}$, the authors found that most of the organisms, which produce enzymes capable of degrading RNA into 5'-mononucleotides, produce the enzymes which catalyze the degradation of DNA, yielding, among other products, 5'deoxymononucleotides.

On the other hand, the enzymes, which are produced in the culture media by various microorganisms, such as Rhodotorula glutinis or Sporoboromyces pararoseus and which degrade RNA into 3'-mononucleotides, do not hydrolyze DNA. Koerner ${ }^{10}$ ) reported that the splenic phosphodiesterase do not hydrolyze highly polymerized DNA but degrade a splenic DNase II digest, that is polydeoxyribonucleotides having 3 '-phosphomonoester end groups, to 3 -deoxymononucleotides. Therefore, the question whether the microbial phosphodiesterase, being not able to hydrolyze 10) J.F. Koerner and R.L. Sinsheimer, J. Biol. Chem., 2281049 (1957). 
DNA, degrade polydeoxyribonucleotides with terminal 3'-monoesterified phosphate as well as the splenic phosphodiesterase still remains to be solved. RNA-depolymerases in the culture media of Acrocylindrium spec., Cunninghamella echinulata, Pestalotia diospyri, and Pestalotiopsis funerea were active at the acid $\mathrm{pH}$ and hydrolyzed DNA into 3'-mononucleotides, while DNA-depolymerases in them were active at the alkaline $\mathrm{pH}$ and hydrolyzed DNA into 5'-deoxymononucleotides. Therefore, these microorganisms seem to produce at least two enzyme systems, one of which catalyzes the decomposition of RNA and another degrades DNA.

Cunningham et al. ${ }^{11)}$ described an enzyme in the culture medium of Micrococcus pyogenes that catalyze the degradation of DNA, yielding the 3'-deoxymononucleotides. Guschlbauer and Halleck ${ }^{12}$ ) reported that Pseudomonas aeruginosa produce both extracellular and intracellular DNases. However, we failed to detect DNA-hydrolyzing enzyme in the culture media of both genera of micro-

\footnotetext{
11) L. Cunningham, B.W. Catlin and M. Privat De Garilhe, J. Am. Chem. Soc., 78, 4642 (1956)

12) W. Guschlbauer and F.E. Halleck, Z. physiol. Chem., 323, 121 (1961).
}

organisms. It is likely that the discrepancy between these results is due to the difference in strains and culture conditions employed.

In the course of this study, we employed UPCA solution as a precipitant instead of $3 \mathrm{~m}$ TCA used by McDonald. The former precipitates the degradation product of DNA by DNase $\mathrm{I}^{4}$ or DNase $\mathrm{II}^{13}$ ) but the latter not. Therefore our screening tests detect no enzymes resembling DNase I or II and it is conceivable that these types of enzymes may be found in other microorganisms than those described above.

The details of the characters of microbial enzymes which concerned with the degradation of DNA are now being investigated.

Acknowledgements. The authors are indebted to Dr. S. Kuwada, Dr. K. Sato, Dr. S. Tatsuoka, Dr. M. Abe and Dr. T. Omura for their interests and encouragements. They wish to express their thanks to Dr. T. Hasegawa for supply of strains and to Dr. M. Yoneda and Mr. I. Suhara for the gift of 5'-nucleotidase and non-specific phosphomonoesterase and to Mr. S. Mori for his assistance.

13) J.F. Koerner and R.L. Sinsheimer, J. Biol. Chem., 228, 1039, 1049 (1957). 